\title{
Determination of Irbesartan Using Stability Indicating Reverse Phase Liquid Chromatographic and UV Spectrophotometric Method
}

\author{
Sumanta Mondal ${ }^{1} *$, Arindam Pal', Prasenjit Mondal' ${ }^{2}$, Dipankar Shit ${ }^{1}$, Sabyasachi Biswal', Beemarasetti Mohan Babu ${ }^{1}$ \\ 'Department of Pharmaceutical Chemistry, Institute of Pharmacy, GITAM (Deemed to be University), Visakhapatnam, Andhra Pradesh, INDIA. \\ ${ }^{2}$ Department of Pharmaceutical Chemistry, Vaageswari Institute of Pharmaceutical of Pharmaceutical Sciences, Ramakrishna Colony, Karimnagar, Telangana, INDIA.
}

\begin{abstract}
Objectives: The present research work involve the development of a novel UV-Spectrophotometric and stability-indicating RP-HPLC methods for the irbesartan in bulk as well as tablet dosage form. Methods: The RP-HPLC method is performed on the Phenomenex $C_{18}$ column $(150 \times 4.6 \mathrm{~mm}$, $5 \mu \mathrm{m})$ particle size, using $0.1 \%$ Formic acid buffer (pH 3.2): Acetonitrile $(60: 40 \mathrm{v} / \mathrm{v})$ as the mobile phase at a flow rate of $1.0 \mathrm{~mL} / \mathrm{min}$ at the $220 \mathrm{~nm}$ detection wavelength. For the UV method the $0.1 \%$ formic acid was used as solvent. Validation study was performed for both the methods as per ICH guidelines. Results: A linear range of $1.5-120 \mu \mathrm{g} / \mathrm{mL}$ for HPLC and 1.75$110.5 \mu \mathrm{g} / \mathrm{mL}$ for UV method was obtained with a correlation coefficient of 0.998 for UV and 0.999 for HPLC method. The retention time of irbesartan was found 2.226 min using optimised condition. In force degradation study the acidic and alkaline conditions decomposes the irbesartan more in compared to other stressed conditions. In UV method the measurement of the absorbance of Irbesartan at $\lambda_{\max }$ equals to $220 \mathrm{~nm}$. The developed
\end{abstract}

UV and HPLC methods was found suitable to assay the marketed tablet dosage form with the percentage purity values of $95.78 \%$ and $96.68 \%$. All the other validation parameters were found within the limit that has been conducted as per the ICH guidelines. Conclusion: The developed methods were found novel, reliable and easy for the estimation of irbesartan in bulk and tablet dosage form.

Key words: HPLC, UV, Irbesartan, Method development, ICH Guidelines.

\section{Correspondence}

Dr. Sumanta Mondal

Associate Professor and NSS Programme Officer (Unit-IX), Institute of Pharmacy, GITAM (Deemed to be University), Visakhapatnam-530045, Andhra Pradesh INDIA.

Phone no: +91-9703615761

Email: mondalresearch@gmail.com

DOI: 10.5530/ijpi.2020.1.13

\section{INTRODUCTION}

Irbesartan is chemically known as 2-butyl-3-(\{4-[2-(2H-1,2,3,4-tetrazol5-yl)phenyl]phenyl\}methyl)-1,3-diazaspiro[4.4]non-1-en-4-one. Irbesartan is an imidazole derivative with a bipenyl-tetrazole side chain shown in Figure 1. It does not require biotransformation to exert its pharmacological action. The molecule has a high affinity for the AT1 receptor in human vascular smooth muscle cells, inducing in vitro a rightward shift of the angiotensin II concentration-response curve and a depression of the maximal response to angiotensin II characteristic of insurmountable blockade of AT1 receptors. ${ }^{1}$ Angiotensin II subtype 1 receptor (AT1R) antagonists are as effective or more effective in treating these conditions compared with ACE inhibitors. ${ }^{2}$ Used as mono therapy or in association with hydrochlorothiazide, irbesartan is an effective antihypertensive drug in a variety of mild-to-moderate hypertensive populations, including patients with diabetes, obesity, renal insufficiency and cardiovascular disease. In comparative trials, irbesartan is at least as effective and sometimes superior to comparator agents of the major antihypertensive classes. ${ }^{3}$ Extensive review of literature on irbesartan estimation reveals that few spectrophotometric methods. ${ }^{4,5}$ One HPTLC method, ${ }^{6}$ simultaneous estimation of irbesartan with other combination $^{7,8}$ has been available. Only two RP-HPLC methods were found for the estimation of irbesartan alone. In one method, ${ }^{9}$ the retention time of irbesartan was found $11.93 \mathrm{~min}$, which is consider too long in method optimization with a linearity range of $10-200 \mu \mathrm{g} / \mathrm{mL}$. In another method, ${ }^{10}$ the determination of irbesartan was reported along with other related impurities, where they reported $5.8 \mathrm{~min}$ as a retention time for irbesartan. Keeping on view of the reported articles and their reported values with disadvantages, this can be state that there is a need to have a clear, easy, reliable validated UV and HPLC method for the estimation of irbesartan alone, which should successively utilize for the determination of irbesartan in marked formulation also. Therefore in this present research work, effort has been taken to minimize all the reported disadvantages and to develop a fast, easy, reliable stability indicating. ${ }^{11} \mathrm{UV}$ and HPLC method for the determination of irbesartan and to validate ${ }^{12}$ as per the ICH Q2B guidelines.

\section{MATERIALS AND METHODS}

\section{Chemicals}

The required HPLC grade solvents eg. Methanol, acetonitrile, collected from the Merck, Mumbai. HPLC grade water was procured from Millipore. All other reagents were of AR grade (RANKEM) purchased from avantor performance materials India limited, Maharashtra. All active pharmaceutical ingredients (API's) of Irbesartan as reference standards were procured from spectrum labs, Hyderabad, India. Marketed formulation (Irovel tablet, Sun Pharma) was purchased from local market of Visakhapatnam, India.

\section{Instrumentation and Chromatographic condition}

The HPLC method was performed on a WATERS HPLC 2695 SYSTEM equipped with quaternary pumps, auto sampler integrated with Empower 2 Software. The method was conducted using a reversed-phase 


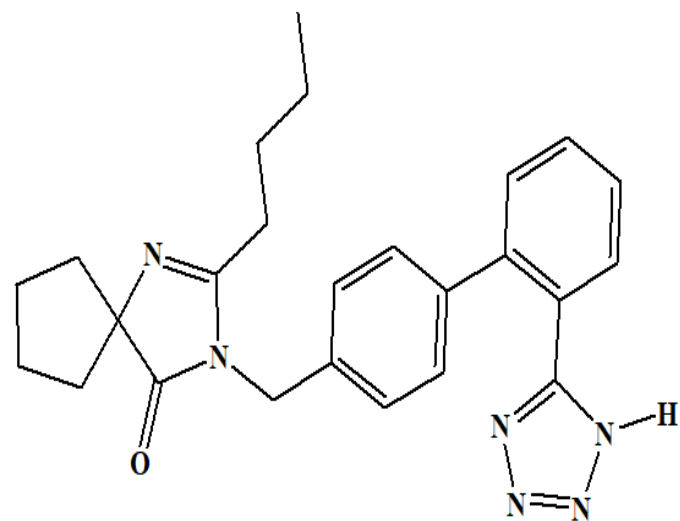

Figure 1: Chemical structure of Irbesartan.

technique. Irbesartan was eluted isocratically with a flow rate of $1.0 \mathrm{ml} /$ min using a mobile phase consisting of $0.1 \%$ Formic acid buffer and Acetonitrile $(60: 40 ; \mathrm{v} / \mathrm{v})$ at $220 \mathrm{~nm}$. Phenomenex $\mathrm{C}_{18}$ analytical column ( $150 \mathrm{~mm}, 4.0 \mathrm{~mm}$ i.d., $5 \mu \mathrm{m}$ particle size) was used. The prepared mobile phase also used as a diluent UV method was performed on a UV-visible Spectrophotometer PG Instruments T60 at $220.0 \mathrm{~nm}$ using $2.0 \mathrm{~cm}$ quartz cells and UV win 6 software was used for all absorbance measurements.

\section{High performance liquid chromatographic method development and validation}

\section{Preparation of standard and working solution for HPLC method}

Accurately weighed $37.5 \mathrm{mg}$ of Irbesartan transferred $50 \mathrm{ml}$ and volumetric flasks; $5 \mathrm{~mL}$ of acetonitrile was added to dissolve and sonicated for 10 min. Flasks were made up to the mark with diluents and labeled as standard stock solution $(750 \mu \mathrm{g} / \mathrm{ml}$ of irbesartan) from this solution working standard solution $100 \mu \mathrm{g} / \mathrm{mL}$ was prepared. The further diluted concentrations of $18.75,37.5,56.25,75,93.75$ and $112.55 \mu \mathrm{g} / \mathrm{mL}$ were made in $10 \mathrm{~mL}$ volumetric flask.

\section{Preparation of sample for the assay of marketed formulations for HPLC method}

10 tablets were weighed and calculate the average weight of each tablet then the tablet powder equivalent to $150 \mathrm{mg}$ of irbesartan was transferred into a $100 \mathrm{~mL}$. Volumetric flask, $25 \mathrm{~mL}$ of diluent added and sonicated for $50 \mathrm{~min}$, further the volume made up with diluent and filtered. From the filtered solution $1 \mathrm{ml}$ was pipette out into a $100 \mathrm{ml}$ volumetric flask and made up to the with diluents. This final diluted sample was injected into chromatographic system.

\section{Accuracy}

To study the accuracy of the proposed method, recovery studies were carried out by adding different amounts of pure drug of irbesartan to the pre-analysed formulation of concentration to achieve various levels $(50 \%, 100 \%$ and $150 \%)$. All levels of the samples were injected in to chromatographic system and percentage recovery values were calculated.

\section{Precision}

Intraday and Inter day

To evaluate the intermediate precision which is also considered as ruggedness, was performed on different day. The standard solutions prepared in the precision was injected on the other day, for six times and measured the area for all six injections in HPLC. The \%RSD for the area of six replicate injections was found to be within the specified limits. The percent relative standard deviation was calculated.

\section{Repeatability}

The precision of each method was ascertained separately from the peak areas and retention times obtained by actual determination of six replicates of a fixed amount of drug irbesartan. The percent relative standard deviation was calculated.

\section{Specificity}

The specificity of the optimised method was carried out by placebo interference test of the sample solution using $500 \mathrm{mg}$ of placebo equivalent to one tablet dissolved in $100 \mathrm{ml}$ of mobile phase and the placebo solution was treated like a standard solution. The solution was injected to the chromatographic system to evaluate the possible interfering peaks.

\section{System suitability}

This study was evaluated to verify whether analytical system is working properly, by injecting the standard drugs of irbesartan six times. The RSD of the parameters like theoretical plates, peak area, retention time and asymmetric factor were calculated.

\section{Linearity}

The linearity justifies the ability of the developed method to obtain test results which are directly proportional to the concentration of analyte in the sample. For this study the solution was prepared in the range of 1.5$120 \mu \mathrm{g} / \mathrm{ml}$ and injected. Regression coefficient was calculated by plotting a graph between concentration of the test solution on $\mathrm{X}$-axis and response of the corresponding solutions on Y-axis.

\section{LOD and LOQ}

Limits of detection and quantification were calculated directly from the calibration curve using working standard solution. LOD and LOQ were calculated as $3.3 \sigma / \mathrm{S}$ and $10 \sigma / \mathrm{S}$ respectively. Where $\sigma$ is the standard deviation of intercept and $\mathrm{S}$ is the slope of the calibration plot.

\section{Robustness}

This was performed to investigate the effect of small deliberate changes in the chromatographic conditions such as change in Temperature $\left( \pm 2^{\circ} \mathrm{C}\right)$, flow rate $( \pm 0.1 \mathrm{ml} / \mathrm{min})$ and organic phase content in mobile phase $( \pm 2 \%)$ were studied to determine the robustness of the developed.

\section{Stability Studies}

\section{Acid degradation}

$10 \mathrm{mg}$ of pure drug was transferred to a clean and dry round bottom flask. $30 \mathrm{ml}$ of $0.1 \mathrm{~N} \mathrm{HCl}$ was added to it and it was refluxed in a water bath at $60^{\circ} \mathrm{C}$ for $4 \mathrm{hr}$. Allowed to cool to room temperature. The sample was then neutralized using dilute $\mathrm{NaOH}$ solution and final volume of the sample was made up to $100 \mathrm{ml}$ with mobile phase to prepare $40 \mu \mathrm{g} / \mathrm{ml}$ solution. It was injected into the HPLC system against a blank of mobile phase (after optimizing the mobile phase compositions). This experiment was repeated several times using same concentration of $\mathrm{HCl}(0.1 \mathrm{~N})$ and observed its degradation profile.

\section{Basic hydrolysis}

$10 \mathrm{mg}$ of pure drug was accurately weighted and transferred to a clean and dry round bottom flask. $30 \mathrm{ml}$ of $0.1 \mathrm{~N} \mathrm{NaOH}$ was added to it and it was refluxed in a water bath at $60^{\circ} \mathrm{C}$ for $4 \mathrm{hr}$. Allowed to cool at room temperature. The sample was than neutralized using $2 \mathrm{~N} \mathrm{HCl}$ solution and final volume of the sample was made up to $100 \mathrm{ml}$ with mobile phase and finally diluted to $10 \mathrm{~mL}$ to prepare $10 \mu \mathrm{g} / \mathrm{ml}$ solution. It was injected into the HPLC system against a blank of mobile phase after optimizing the mobile phase compositions. This experiment was repeated several 
times using same concentration of $\mathrm{NaOH}$ such as $0.1 \mathrm{~N}$ to observe its degradation profile is the degradation profile of irbesaran in $0.1 \mathrm{~N} \mathrm{NaOH}$.

\section{Thermal degradation}

Accurately weighed $10 \mathrm{mg}$ of pure drug was transferred to a clean and dry round bottom flask. $30 \mathrm{ml}$ of HPLC water was added to it. Then, it was refluxed in a water bath at $60^{\circ} \mathrm{C}$ for $6 \mathrm{hr}$ uninterruptedly. After the reflux was over, the drug became soluble and the mixture of drug and water was allowed to cool to room temperature. Final volume was made up to $100 \mathrm{ml}$ and finally diluted to $10 \mathrm{~mL}$ to prepare $10 \mu \mathrm{g} / \mathrm{ml}$ solution. It was injected into the HPLC system against a blank of mobile phase.

\section{Photolytic degradation}

Approximately $10 \mathrm{mg}$ of pure drug was taken in a clean and dry Petri dish. It was kept in a UV cabinet at $254 \mathrm{~nm}$ wavelength for $24 \mathrm{hr}$ without interruption. Accurately weighed $1 \mathrm{mg}$ of the UV exposed drug was transferred to a clean and dry $10 \mathrm{ml}$ volumetric flask. First the UV exposed drug was dissolved in methanol and made up to the mark with mobile phase and finally diluted to $10 \mathrm{~mL}$ to prepare $10 \mu \mathrm{g} / \mathrm{ml}$ solution. This solution was injected into the HPLC system against a blank of mobile phase and chromatogram was obtained.

\section{Oxidative hydrolysis $\left(3 \% \mathrm{H}_{2} \mathrm{O}_{2}\right)$}

Accurately weighed $10 \mathrm{mg}$ of pure drug was taken in a clean and dry 100 $\mathrm{ml}$ volumetric flask. $30 \mathrm{ml}$ of $3 \% \mathrm{H}_{2} \mathrm{O}_{2}$ and a little methanol was added to it to make it soluble and then kept as such in dark for $24 \mathrm{hr}$. Final volume was made up to $100 \mathrm{ml}$. using water and finally diluted to $10 \mathrm{~mL}$ to prepare $10 \mu \mathrm{g} / \mathrm{ml}$ solution. The above sample was injected into the HPLC system against a blank of mobile phase and chromatogram was obtained.

\section{UV spectrophotometric method development and validation}

\section{Preparation of Standard and working solution for UV estimation method}

Accurately weighed $7.5 \mathrm{mg}$ of Irbesartan was dissolved in a little quantity of methanol and then made up to $10 \mathrm{ml}$ to get a concentration of 750 $\mu \mathrm{g} / \mathrm{ml}$. From the standard stock solution, an aliquot of $1 \mathrm{ml}$ was taken and made up to $10 \mathrm{ml}$ with $0.1 \%$ Formic acid as blank to get a working standard stock solution of concentration $75 \mu \mathrm{g} / \mathrm{ml}$. From the working standard stock solution, various diluted samples were prepare by withdrawing the aliquots of $0.2 \mathrm{ml}, 0.4 \mathrm{ml}, 0.5 \mathrm{ml}, 0.8 \mathrm{ml}, 1 \mathrm{ml}$ and $1.2 \mathrm{ml}$ and made up to $10 \mathrm{ml}$ with $0.1 \%$ Formic acid as blank to get working solutions of concentration $1.5,3,3.75,6,7.5$ and $9 \mu \mathrm{g} / \mathrm{ml}$, respectively.

\section{Determination of absorption maxima $\left(\lambda_{\max }\right)$}

The working solutions were spectrum scanned in the wavelength range of $200-400 \mathrm{~nm}$ by using $0.1 \%$ Formic acid as blank. The wavelength at which the spectra showed the maximum absorbance was noted as $\lambda_{\max }$.

Construction of calibration curve: Three series of working solutions were prepared and measured for absorbance in triplicate at $220 \mathrm{~nm}\left(\lambda_{\max }\right)$ and a calibration curve was plotted by taking concentration on $y$-axis and average absorbance on $\mathrm{x}$-axis.

\section{Assay of Marketed dosage form}

Accurately 10 tablets were weighed and the average weight of each tablet has been calculated then the tablet powder equivalent to $150 \mathrm{mg}$ of irbesartan was transferred into a $100 \mathrm{~mL}$ volumetric flask, $25 \mathrm{~mL}$ of methanol was added and sonicated for $5 \mathrm{~min}$, further the volume made up with $0.1 \%$ firmic acid and filtered. From the filtered solution $1 \mathrm{ml}$ was pipette out into a $100 \mathrm{ml}$ volumetric flask and the volume was made up to the mark with $0.1 \%$ formic acid.

\section{Method Validation}

The developed UV method for irbesartan was performed by optimizing the UV spectrophometric parameters eg. Solvent selection, $\lambda_{\max }$ identification, linearity. The method was validated by studying the following validation parameters as per ICH guidelines for UV spectrophotometric method validation.

Linearity: The calibration curve was obtained with five concentrations of the standard solution, as $1.75-110.5 \mu \mathrm{g} / \mathrm{ml}$ for UV method. The solutions were prepared in triplicate. The linearity was evaluated by linear regression analysis, which was calculated by the least square regression method.

\section{Recovery Studies}

Recovery study was performed to access the accuracy of the developed method. A fixed amount of drug from dosage form was taken and pure standard drug at different concentrations within Beer's range was added the total concentration was found by the proposed method. The determination with each concentration was repeated three times and average percent recovery of the added standard was calculated.

\section{Repeatability / Precision}

The content of the drug in the working solution was determined using calibration curve 5 times in a day for intraday precision and on five different days for inters day precision. The average $\%$ RSD was calculated.

\section{Limits of Detection and Quantification.}

Calibration curve was prepared for 5 times at $220 \mathrm{~nm}$ and SD of the intercept was calculated for the drug. The LOD and LOQ are calculated.

\section{Robustness}

The Robustness of an analytical method is a measure of its capacity to remain unaffected by small but deliberate variations in method parameters and provides an indication of its reliability during normal stage. Here the robustness of the method was determined by small changing the measurement wavelength and the drug content was determined.

\section{RESULTS}

\section{HPLC Method optimization}

During the HPLC method development study, before to select the optimised chromatographic condition several of preliminary trials has been conducted with different combination of solvents, flow rate, various buffers, $\mathrm{pH}$, temperature and columns in order to justify the retention time, peak shape, resolution and other chromatographic parameters. Various analytical columns were tested with U.V detection at $220 \mathrm{~nm}$. Finally a selected mobile phase consisting of $0.1 \%$ formic acid buffer and acetonitrile $(60: 40 ; \mathrm{v} / \mathrm{v})$ at $220 \mathrm{~nm}$. Phenomenex $\mathrm{C}_{18}$ analytical column $(150 \mathrm{~mm}$, $4.0 \mathrm{~mm}$ i.d., $5 \mu \mathrm{m}$ particle size) was used at the flow rate of $1 \mathrm{~mL} / \mathrm{min}$, the chromatographic conditions were successfully separated at $2.22 \mathrm{~min}$ retention time for irbesartan with a better sensitivity and excellent peak shape, shown in Figure 2.

\section{Method Validation by developed HPLC method}

The subsequent validation study and force degradation study as per ICH guidelines were conducted by utilizing the optimised chromatographic condition. In the study of specificity no correspond peak was found at the retention time of the analyte. In the study of system suitability, parameters like tailing factor and theoretical plates were be taken into con- 
sideration. The \%RSD of theoretical plates, tailing factors and retention time were $0.56 \%, 0.78 \%, 0.68 \%$ and $0.52 \%$ respectively.

The assay of tablet "Avapro" (150 mg irbesartan) using developed HPLC method was conducted and the amount of drug was found $145.02 \mathrm{mg}$ and $\%$ assay was $96.68 \%$. The details was given in Table 1 and chromatogram was shown in Figure 3. The calibration curve showed linearity in the range of $1.5-120 \mu \mathrm{g} / \mathrm{mL}$, for irbesartan (API) with correlation coefficient $\left(r^{2}\right)$ of 0.999 . The limit of detection (LOD) and limit of quantified (LOQ) were found to be 0.40 and $0.13 \mu \mathrm{g} / \mathrm{ml}$ respectively. The chromatograms of detection and quantitation were shown in Figure 5. In the study of intra and interday precision, the \% RSD was found 0.72 and 0.91 . The results of the validation parameters were included in Table 2. The average recovery of the irbesartan using HPLC method was $97.68 \%$, details of the results shown in Table 3. The method was found robust with the change in flow rates from $\pm 0.1 \mathrm{~mL} / \mathrm{min}, 0.1 \%$ formic acid buffer and acetonitrile ratios (62: 38, 58: 42 and), Detection wave-

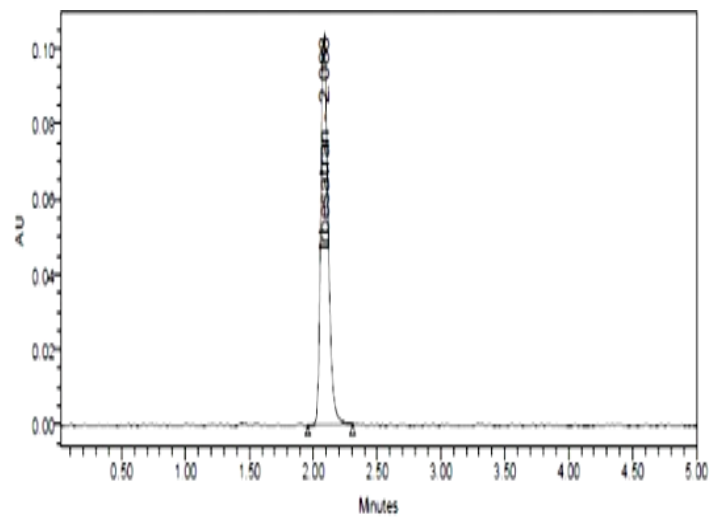

Figure 2: Optimised chromatogram of irbesartan.

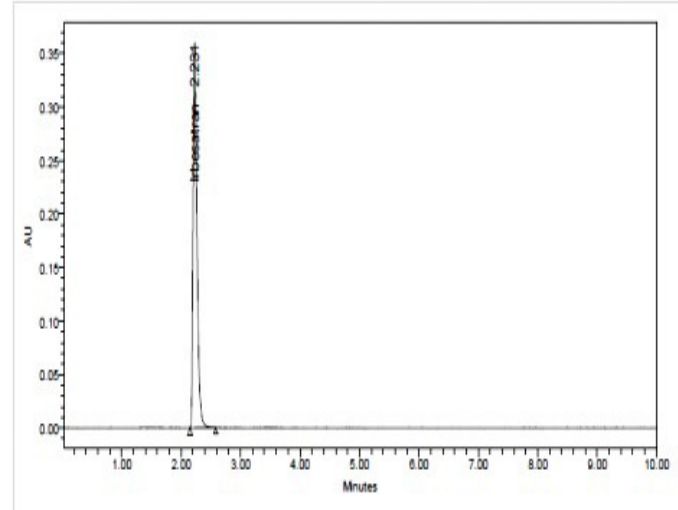

Figure 3: Chromatogram of irbesartan tablet assay.

Table 1: Assay of marketed dosage form by UV and HPLC method.

\begin{tabular}{cccccc}
\hline Formulation & $\begin{array}{c}\text { Label Claim } \\
(\mathrm{mg})\end{array}$ & \multicolumn{2}{c}{$\begin{array}{c}\text { *Amount found } \\
(\mathrm{mg})\end{array}$} & \multicolumn{2}{c}{$\%$ purity } \\
\cline { 3 - 6 } & & $\begin{array}{c}\text { UV } \\
\text { method }\end{array}$ & $\begin{array}{c}\text { HPLC } \\
\text { method }\end{array}$ & $\begin{array}{c}\text { UV } \\
\text { method }\end{array}$ & $\begin{array}{c}\text { HPLC } \\
\text { method }\end{array}$ \\
\hline $\begin{array}{c}\text { AVAPRO } \\
\text { (Irbesartan } \\
\text { 150mg) }\end{array}$ & $150 \mathrm{mg}$ & 143.67 & 145.02 & 95.78 & 96.68 \\
\hline
\end{tabular}

* Average of Three experiments
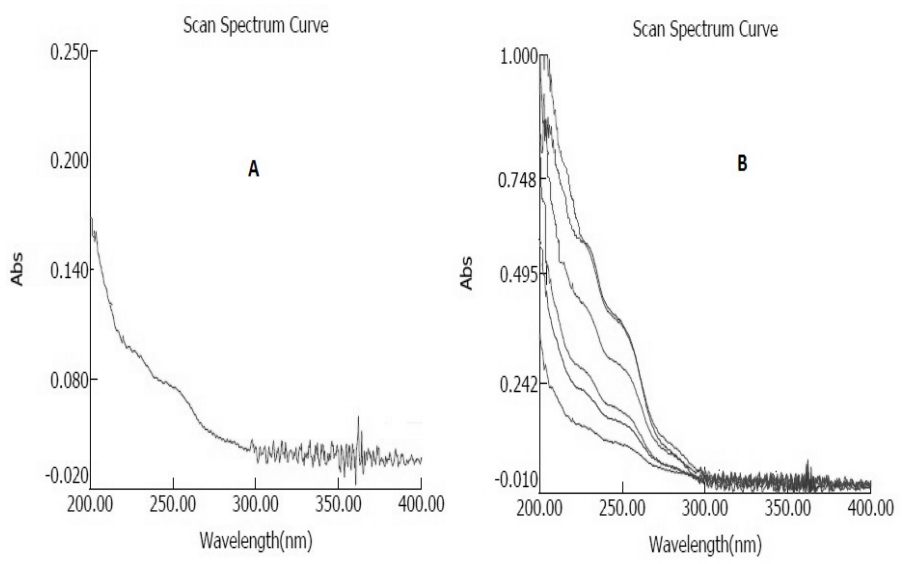

Figure 4: Optimised (A) and linear (B) UV spectrum of Irbesartan.
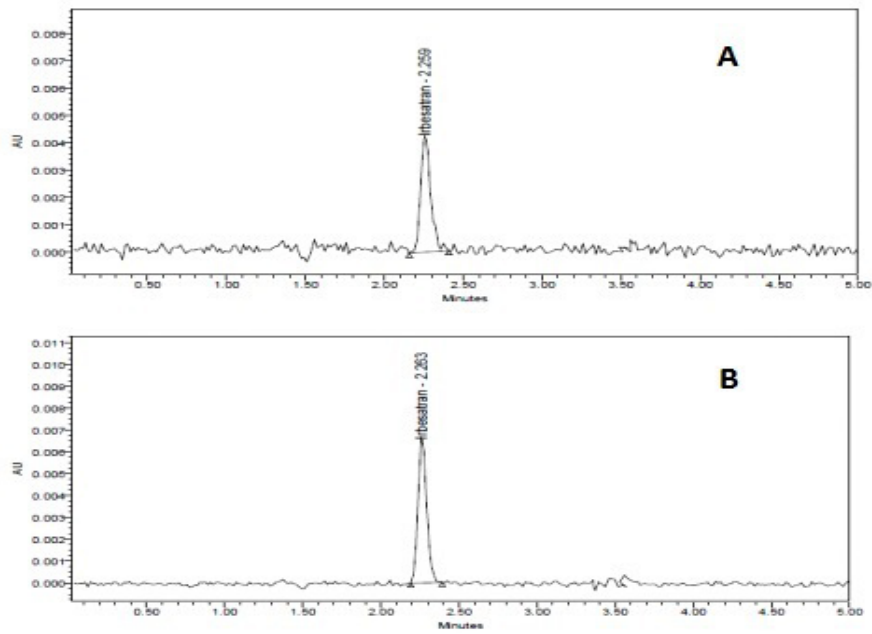

Figure 5: Limit of detection (A), Limit of quantitation (B) chromatograms of irbesartan.

Table 2: Summary of validation parameters.

\begin{tabular}{ccc}
\hline Parameters & Irbesartan by UV & Irbesartan by HPLC \\
\hline Linearity range $(\mu \mathrm{g} / \mathrm{ml})$ & $1.75-110.5$ & $1.5-120$ \\
Intraday Precision (\% & 0.12 & 0.72 \\
RSD) & 0.17 & 0.91 \\
Interday Precision (\% & 0.998 & 0.999 \\
RSD) & 0.27 & 0.04 \\
Regression coefficient & 0.82 & 0.13 \\
LOD $\mu \mathrm{g} / \mathrm{ml}$ & $\mathrm{LOQ} \mu \mathrm{g} / \mathrm{ml}$ &
\end{tabular}

length $(222 \mathrm{~nm}, 224 \mathrm{~nm})$. The details of the study results are presented in Table 4 . The stress degradation study were conducted in various stressed condition and \% degrading was calculated. It was observed that in acidic and alkaline stressed conation the percentage degradation were $25.60 \%$ and $26.26 \%$. The percentage degradation $17.38 \%$ was found in peroxide induced stressed condition. The thermal and UV condition the \% degradation were $15.95 \%$ and $5.43 \%$. The details was given in Table 5 and degradation chromatograms were cited in Figure 6 
Table 3: Recovery studies of irbesartan by UV and HPLC method.

\begin{tabular}{|c|c|c|c|c|c|c|c|c|}
\hline \multirow[t]{2}{*}{ Formulation } & \multirow{2}{*}{$\begin{array}{l}\text { Label } \\
\text { Claim in } \\
\text { mg }\end{array}$} & \multirow{2}{*}{$\begin{array}{c}\text { Conc. of pure } \\
\text { drug added in } \\
\text { mg }\end{array}$} & \multicolumn{2}{|c|}{$\begin{array}{l}\text { * Amount of drug found } \\
\text { in } \mathrm{mg}\end{array}$} & \multicolumn{2}{|c|}{$\%$ Recovery \pm SD } & \multicolumn{2}{|c|}{ Avg $\% \pm S D$} \\
\hline & & & UV method & $\begin{array}{l}\text { HPLC } \\
\text { method }\end{array}$ & $\begin{array}{c}\text { UV } \\
\text { method }\end{array}$ & HPLC method & $\begin{array}{c}\text { UV } \\
\text { method }\end{array}$ & $\begin{array}{l}\text { HPLC } \\
\text { method }\end{array}$ \\
\hline \multirow[b]{4}{*}{$\begin{array}{l}\text { (Avapro } 150 \\
\mathrm{mg})\end{array}$} & 150 & -- & 143.57 & 144.28 & $95.71 \pm 0.124$ & $96.18 \pm 0.154$ & \multirow{4}{*}{$97.43 \pm 0.133$} & \multirow{4}{*}{$97.68 \pm 0.146$} \\
\hline & -- & 100 & 245.03 & 246.65 & $98.01 \pm 0.154$ & $98.66 \pm 0.173$ & & \\
\hline & -- & 200 & 343.96 & 342.56 & $98.27 \pm 0.262$ & $97.87 \pm 0.109$ & & \\
\hline & -- & 300 & 439.86. & 441.08 & $97.74 \pm 0.106$ & $98.01 \pm 0.146$ & & \\
\hline
\end{tabular}

* Average of three determinations

Table 4: Robustness study.

\begin{tabular}{cc}
\hline Change in parameter & $\%$ RSD \\
\hline Flow $(1.1 \mathrm{ml} / \mathrm{min})$ & 0.94 \\
Flow $(0.9 \mathrm{ml} / \mathrm{min})$ & 0.89 \\
Mobile phase ratio(+2) & 0.78 \\
Mobile phase ratio(-2) & 0.81 \\
Wavelength of Detection $(218 \mathrm{~nm})$ & 0.93 \\
Wavelength of detection $(222 \mathrm{~nm})$ & 1.27 \\
\hline
\end{tabular}

Table 5: Stress degradation study.

\begin{tabular}{|c|c|c|c|c|}
\hline S.NO & $\begin{array}{l}\text { Degradation } \\
\text { Condition }\end{array}$ & $\begin{array}{c}\% \text { Drug } \\
\text { Degraded }\end{array}$ & Purity Angle & $\begin{array}{l}\text { Purity } \\
\text { Threshold }\end{array}$ \\
\hline 1 & $\begin{array}{c}\text { Acid Hydrolysis }(0.1 \\
\mathrm{M} \mathrm{HCl})\end{array}$ & 25.60 & 0.167 & 0.369 \\
\hline 2 & $\begin{array}{c}\text { Alkali Basic } \\
\text { Hydrolysis (0.I M } \\
\mathrm{NaOH})\end{array}$ & 26.26 & 0.185 & 0.372 \\
\hline 3 & $\begin{array}{l}3 \% \text { Hydrogen } \\
\text { peroxide }\end{array}$ & 17.38 & 0.212 & 0.427 \\
\hline 4 & $\begin{array}{c}\text { Thermal Degradation } \\
\left(60^{\circ} \mathrm{C}\right)\end{array}$ & 15.95 & 0.156 & 0.374 \\
\hline 5 & UV (254nm) & 5.43 & 0.195 & 0.311 \\
\hline
\end{tabular}
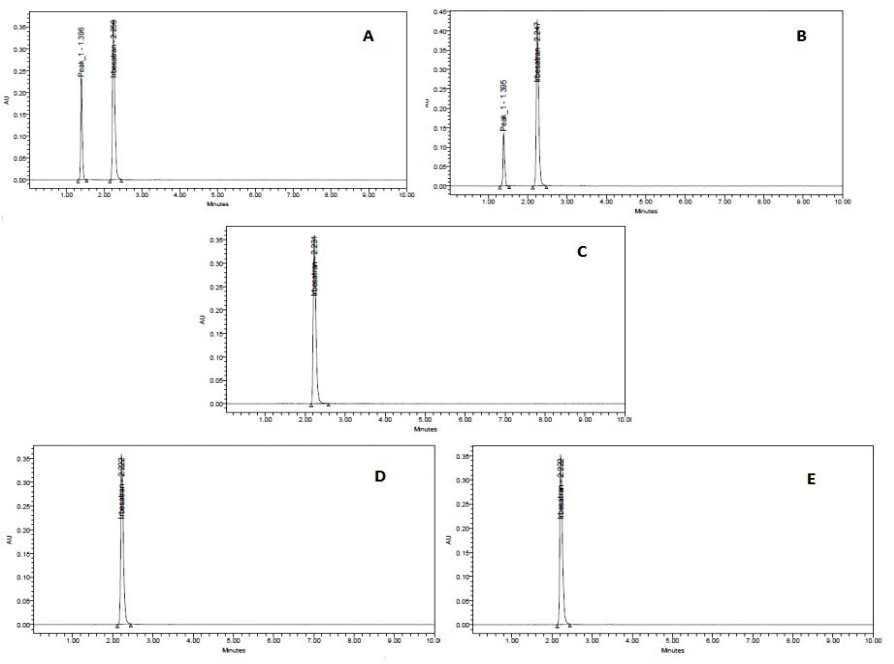

Figure 6: Chromatograms of force degradation study, Acidic (A), Alkaline (B), Peroxide (C), Thermal (D), Photo (E).

\section{UV Optimization}

To determine the suitable solvent system to obtain the linear UV spectrum of irbesartan various solvents, mixture of solvents and buffer systems at several volume ratios were tested. Finally methanol as a dissolving solvent and $0.1 \%$ formic acid was utilized to optimize the solvent system and also utilize for subsequent validation study. The optimised spectrum and overlay spectrum was shown in Figure 4. With this solvent system the linear UV spectrum were obtained at the $\lambda_{\max } 220 \mathrm{~nm}$ as shown in optimised spectrum Figure. The above solvent system also used for the assay of marketed dosage form.

\section{Method validation by developed UV spectroscopy method}

The optimised method was applied for the estimation of irbesartan in marketed dosage form "Avapro" (150 mg irbesartan). The obtained amount was $143.67 \mathrm{mg}$ and the percentage purity was $95.78 \%$, shown in Table 1 . The linearity study of the developed method was found linear in the range of $1.75-110.5 \mu \mathrm{g} / \mathrm{ml}$, with a regression coefficient $\left(R^{2}\right)$ of 0.998 , cited in Table 2. In accuracy study of the developed method the average percentage recovery of irbesartan was found $97.43 \%$, as shown in Table 3 . The average $\%$ RSD for the intraday and interday precision study was found 0.12 and 0.17 . In the study of limit of detection and limit of quantitation, limit was found $0.27 \mu \mathrm{g} / \mathrm{ml}$ and 0.82 quantitation limit was found $0.389 \mu \mathrm{g} / \mathrm{ml}$ for irbesartan. The details of these values included in the summary of validation parameters as shown in Table 2 .

\section{DISCUSSION}

The optimised chromatographic conditions, for the developed HPLC method of irbesartan was confirmed with a mobile phase of $0.1 \%$ formic acid buffer and acetonitrile in the ratio of 60:40(v/v) using WATERS HPLC 2695 SYSTEM equipped with phenomenex $\mathrm{C}_{18}$ column, quaternary pumps, photo diode array detector and auto sampler integrated with Empower 2 Software and the flow rate of $1 \mathrm{~mL} / \mathrm{min}$ was found optimum. Irbesartan was eluted with a retention time of 2.22 min with a better sensitivity and excellent peak shape. For the developed UV method of irbesartan methanol as a dissolving solvent and $0.1 \%$ formic acid as bulk solvent was found suitable to optimised the UV spectrum at $220 \mathrm{~nm}$. For both the developed methods the assay of marketed dosage form was found suitable with satisfactory percentage of purity as shown in the results. In the precision study the percentage of RSD using both UV and HPLC methods were found less than 2, which gives a clear indication for the precision of the developed method. In linearity study of both UV and HPLC method, the regression coefficient values were 0.999 and 0.998 , clearly indicates the linearity of the developed methods. The results of average percentage recovery $97.43 \%$ for UV method and $97.68 \%$ for HPLC method which indicated the accuracy of the developed methods as the values are within the acceptance limit. LOD and LOQ study results 
indicated that the both the developed methods was and easily quantifiable and found sensitive to determine irbesartan. The robustness study results of the HPLC method indicates that there is no significant changes in the result on small deliberate changes in detection wavelength, mobile phase ratio and flow rate of the mobile phase in chromatographic system, which indicated that the developed method was robust. In force degradation study there is a very narrow level degradation occurs in most of the decomposition conditions. In comparison to photolytic and thermal degradation, acidic and alkaline stressed conditions caused more decomposition of the irbesartan. The obtained result shows that the drug is resistant to the above degradation conditions, because in every stressed condition the percentage of degradations were found within the limit as per ICH guideline to claimed ${ }^{13}$ the developed method stable.

\section{CONCLUSION}

The empirical evidences of the validation study results indicated that the developed RP-HPLC and UV spectrophotometric methods were highly accurate, precise and robust and are in good agreement with the labeled claim of the drug and obtained assay results. Therefore it can be concluded that, the present methods were highly suitable for the routine analysis of irbesartan in bulk and its tablet dosage form in pharmaceutical quality control laboratory.

\section{ACKNOWLEDGEMENT}

The authors are thankful to the GITAM Institute of Pharmacy, Visakhapatnam, for providing the necessary facilities to carry out the research work.

\section{CONFLICT OF INTEREST}

The authors confirm that this article content has no conflicts of interest.

\section{ABBREVIATIONS}

HPLC: High performance liquid chromatography; ICH: International conference on harmonization; PDA: Photo diode array; LOD: Limit of detection; LOQ: Limit of quantitation; SD: Standard deviation; RSD: Relative standard deviation.

\section{REFERENCES}

1. Herbert JM, Delisée C, Dol F, Schaeffer P, Cazaubon C, Nisato D, et al. Effect of SR47436, a novel angio-tensin II AT1 receptor antagonist, on human vascular smooth muscle cells in vitro. Eur J Pharmacol. 1994;251(2-3):143-50.

2. Kochar M, Guthrie R, Triscari J, Kassler TK, Reeves RA. Matrix study of irbesartan with hydrochlorothiazide in mild-to-moderate hypertension. Am J Hypertens. 1999;12(8):797-805

3. Forni V, Wuerzner G, Pruijm M, Burnier M. Long-term use and tolerability of irbesartan for control of hypertension. Integr Blood Press Control. 2011:4:17-26.

4. Gunjan K, Baikuntha A. Stability Indicating Assay and Estimation of Irbesartan by First Order UV Derivative Spectrophotometry. Int J Pharm Sci Res. 2017;8(9):3817-21.

5. Anupama, Abhinav K, et al. Uv Spectrophotometric Method For Irbesartan. Int J Res Pharm and Chem. 2012;2(1):20-1.

6. Jayaprakash R, Natesan SK. Novel validated stability indicating HPTLC method for the estimation of irbesartan and hydrochlorothiazide in active pharmaceutical ingradients. Int J Pharm Healthcare Res. 2016;4(3):65-78.

7. Rane VP, Patil KR, Sangshetti JN, Yeole RD, Shinde DV. Stability Indicating LC Method for Simultaneous Determination of Irbesartan and Hydrochlorothiazide in Pharmaceutical Preparations. J Chromatogr Sci. 2010;48(7):595-600.

8. Vujic Z, Mulavdic N, Smajic M, Brboric J, Stankovic P. Simultaneous Analysis of Irbesartan and Hydrochlorothiazide: An Improved HPLC Method with the Aid of a Chemometric Protocol. Molecules. 2012;17(3):3461-74.

9. Nagamani M, Sahoo SK, Kavitha D, Vagyalaxmi CH, Mahapatra L. Validated RPHPLC Method for Simultaneous Estimation of Irbesartan and Hydrochlorothiazide in Tablet Dosage Form. Int J Pharm Res and Health Sci. 2017;5(5):1419-23.

10. Rao KT, Rao LV, Kandepi KM, Rapid Stability-indicating RRLC Method for Simultaneous Estimation of Irbesartan and its Related Impurities. Indian J Pharm Sci.2016;78(2):252-8.

11. Mondal P, Shobharani S, Ramakrishna R. Novel stability indicating validated RPHPLC method for simultaneous quantification of Artemether and Lumefantrine in Bulk and Tablet. Curr Pharm Anal. 2014;10(4):271-8.

12. Mondal P, Mahender K, Padmaja B. A Novel UPLC-PDA Method for the Simultaneous Determination of Lamivudine, Zidovudine and Nevirapine in Bulk and Tablet Dosage Form. Anal Chem Let. 2018;8(1):131-8.

13. Venkataraman S, Manasa M. Forced degradation studies: Regulatory guidance, characterization of drugs and their degradation products - a review. Drug. Invention Today. 2018;10(2):137-46.

Cite this article: Mondal S, Pal A, Mondal P, Shit D, Biswal S, Babu BM. Determination of Irbesartan Using Stability Indicating Reverse Phase Liquid Chromatographic and UV Spectrophotometric Method. Int. J. Pharm. Investigation. 2020;10(1):70-5. 